\section{Effect of Plant Growth Retardants on Stem Elongation of Hibiscus Species}

\author{
Ryan M. Warner and \\ John E. Erwin
}

Additional INDEX words. chlormequat chloride, daminozide, paclobutrazol, uniconazole, Hibiscus coccineus, Hibiscus radiatus, Hibiscus trionum

Summary. One-time spray applications [about $6 \mathrm{~mL}(0.2 \mathrm{fl} \mathrm{oz})$ ] of chlormequat chloride [ 1000 or 2000 $\left.\mathrm{mg} \cdot \mathrm{L}^{-1}(\mathrm{ppm})\right]$, daminozide $(2500$ or $\left.5000 \mathrm{mg} \cdot \mathrm{L}^{-1}\right)$, paclobutrazol (20 or $40 \mathrm{mg} \cdot \mathrm{L}^{-1}$ ) and uniconazole ( 5 or 10 $\left.\mathrm{mg} \cdot \mathrm{L}^{-1}\right)$ varied in efficacy in reducing Hibiscus coccineus (Medic.) Walt., $H$. radiatus Cav., and $H$. trionum $\mathrm{L}$.

(flower-of-an-hour) stem elongation. Chlormequat chloride inhibited stem elongation of all species, with a 2000 $\mathrm{mg} \cdot \mathrm{L}^{-1}$ application reducing stem length of $H$. coccineus, $H$. vadiatus, and $H$. trionum by $87 \%, 42 \%$, and $\mathbf{5 2 \%}$, respectively, compared to untreated plants, $28 \mathrm{~d}$ after application. Paclobutrazol also inhibited stem elongation of all species. Uniconazole reduced stem elongation of $H$. coccineus and $H$. vadiatus, but not $H$. trionum. Daminozide applied at $5000 \mathrm{mg} \cdot \mathrm{L}^{-1}$ reduced $H$. vadiatus stem elongation only. Growth retardants examined in this study did not delay flowering of $H$. trionum, the only species that flowered during the experiment. (Chemical names used: ancymidol ( $\alpha$-cyclopropyl- $\alpha-(4-$ methoxyphenol)-5-

pyrimidinemethonol), chlormequat chloride(2-

chloroethyltrimethylammonium chloride), paclobutrazol $\left((+)-\left(\mathbf{R}^{*}, \mathbf{R}^{*}\right)-\right.$ beta((4-chlorophenyl)methyl)-alpha(1,1-dimethyl)-1H-1,2,4-triazol-1ethanol), daminozide ([butanedioic acid mono(2,2-dimethylhydrazide)], uniconazol-P ((E)-(+)-(s)-1-(4-

University of Minnesota, Department of Horticultura Science, 305 Alderman Hall; 1970 Folwell Ave., Saint Paul, MN 55108-6007.

Paper 021210102 of the Department of Horticultural Science, University of Minnesota. This research was funded in part by the Minnesota Agricultural Experiment Station. Mention of trade names in this publication does not imply endorsement by the Minnesota Agriculture Experiment Station of products named, nor criticism of similar products not named. chlorophenyl)-4,4-dimethyl-2-(1,2,4triazol-1-yl)pent-1-ene-3-ol)).

$\mathrm{P}$ lant growth retardants (PGRs) are commonly used to inhibit stem elongation of many ornamental plants. PGRs act by inhibiting cell division in the subapical meristem of the shoot (Gianfaga, 1995; Sachs et al., 1960), or by inhibiting cell elongation (Grossman, 1992). The type of growth inhibition is, in part, dependent on the concentration of growth retardant applied (Grossman, 1988) and species. At low concentrations, growth retardants typically reduce cell elongation, whereas at high concentrations the reduction is increasingly due to a reduced cell division (Grossman, 1992). Although traditional plant breeding and advances in greenhouse environment control have reduced the amount of growth retardants applied to many crops, growth retardants are still commercially used to inhibit stem elongation, enhance foliage color and decrease time to flower (Dole and Wilkins, 1999).

The mode of action of plant growth retarding chemicals varies. Ancymidol (A-Rest; SePRO Corp., Carmel, Ind.), paclobutrazol (Bonzi; Uniroyal Chemical Co., Middlebury, Conn.), and uniconazole (Sumagic; Valent USA Corp., Walnut Creek, Calif.) reduce stem elongation by inhibiting the kaurene oxidation sequence of reactions in the gibberellin biosynthesis pathway (Gianfaga, 1995). Daminozide (B-Nine; Uniroyal Chemical Co.) is reported to act by inhibiting translocation of gibberellins (Menhennet, 1980) and by increasing gibberellin degradation (Takeno et al., 1981). Chlormequat chloride (CCC) (Cycocel; Olympic Horticultural Products Co., Mainland, Pa.) reduces elongation by interfering with the biosynthetic steps directly before ent-kaurene, a precursor in the gibberellin biosynthesis pathway (Rademacher, 1991).

Plant growth retardants are currently used to reduce stem elongation of commercially available hibiscus species (Hibiscus L.) (Dole and Wilkins, 1999). CCC and ancymidol reduce Hibiscus rosa-sinensis L. (chinese hibiscus) stem elongation (Shanks, 1972). Foliar application of CCC $\left(1000 \mathrm{mg} \cdot \mathrm{L}^{-1}\right)$ reduced shoot length of cultivars $H$. rosa- sinensis 'Brilliantissima' and 'Kona' by $51 \%$ and $69 \%$, respectively (Shanks, 1972). CCC application to H. rosasinensis also results in darker green leaf color (Wilkins and Kotecki, 1982). Soaking $H$. rosa-sinensis 'Seminole Pink' unrooted cuttings in $25 \mathrm{mg} \cdot \mathrm{L}^{-1}$ paclobutrazol or uniconazole for $5 \mathrm{~s}$ reduced plant height $25 \%$ and $75 \%$, respectively, after 24 weeks compared to untreated plants (Wang and Gregg, 1991). CCC also reduced height of $H$. syriacus L. (rose-of-sharon), $H$. mutabilis L. (cotton rose), and $H$. sabdariffa L. (roselle) (Bose et al., 1968). Spray applications of either $1000 \mathrm{mg} \cdot \mathrm{L}^{-1} \mathrm{CCC}$ or $15 \mathrm{mg} \cdot \mathrm{L}^{-1}$ uniconazole reduced $H$. moschentos L. (common rose mallow) 'Disco Belle Mixed' stem elongation, although multiple applications appeared to be necessary to produce a commercially acceptable crop (Wang et al., 1998).

We examined numerous hibiscus species for potential commercial use (Warner and Erwin, 2001). Of these, $H$. radiatus and $H$. trionum were identified as being potentially commercially important. Although $H$. coccineus did not flower in the previous study, plants observed in flower ( R. Warner, personal observation) suggest this species may also have commercial potential. However, height of each species at flowering was excessive $[>20 \mathrm{~cm}(8$ inches)] in a $10-\mathrm{cm}$ (4-inch) pot. Therefore, plant height must be reduced in order to make shipping economically feasible and to produce an attractive plant for the consumer. The objective of this experiment was to determine the efficacy of four PGRs in inhibiting stem elongation of the potential new commercial hibiscus species, $H$. coccineus, $H$. radiatus, and $H$. trionum.

\section{Materials and methods}

On 7 and 23 Mar. 1998, $H$. coccineus, $H$. radiatus, and $H$. trionum seeds were soaked for $12 \mathrm{~h}$ in about 75 ${ }^{\circ} \mathrm{C}\left(167^{\circ} \mathrm{F}\right)$ water that was allowed to cool to about $22{ }^{\circ} \mathrm{C}\left(72{ }^{\circ} \mathrm{F}\right)$. Seeds were then sown in 128-cell trays in a soilless medium (Germination Mix; Strong-Lite Horticultural Products, Pine Bluff, Ark.), covered with vermiculite (Premium Grade Medium Vermiculite; Strong-Lite Horticultural Products) to a depth about 1.5 times the diameter of the seed and placed under intermittent mist $(6 \mathrm{~s}$ of mist every $10 \mathrm{~min}$, from 0700 to $1900 \mathrm{HR}$ ) 
Table 1. Effect of plant growth retardant spray application on increase in plant height from day zero to day 14 (Inc 1 ), day 14 to day 28 (Inc 2), day zero to day 28 (Inc total), and the per cent reduction (\%) in height compared to untreated plants of three hibiscus species.

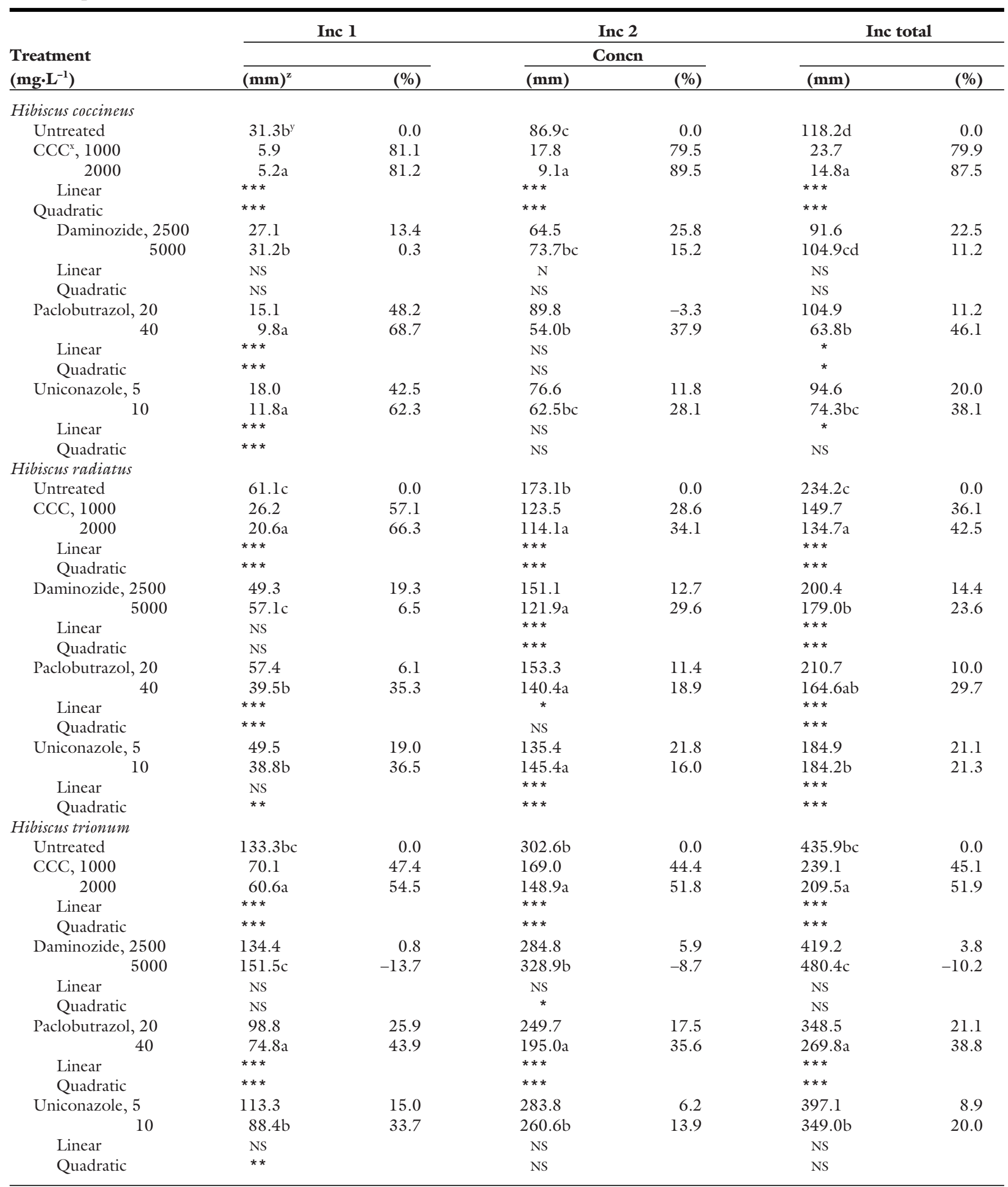

${ }^{\mathrm{z}} 1.0 \mathrm{~mm}=0.039$ inches.

'yowercase letters represent means separation test (Tukey's HSD, $P=0.05$.) comparing growth retardant at the highest rate to untreated plants within species and time point. ${ }^{\mathrm{x}} \mathrm{CCC}=$ chlormequat chloride.

Ns,,$* * * * * *$ Nonsignificant or significant at $P \leq 0.05,0.01$ or 0.001 , respectively. 
at $25 \pm 1{ }^{\circ} \mathrm{C}\left(77 \pm 2{ }^{\circ} \mathrm{F} ; 24\right.$-h mean \pm $\mathrm{SE})$ air temperature. Seedlings were transplanted into $10-\mathrm{cm}$ pots in a soilless medium (Universal Mix, StrongLite Horticultural Products) when cotyledons were parallel to the media surface, and placed in a greenhouse maintained at $20 \pm 1^{\circ} \mathrm{C}\left(68 \pm 2{ }^{\circ} \mathrm{F}\right)$ air temperature under ambient light conditions for $3 \mathrm{~d}$ (St. Paul, Minn.). Transplanting dates were 18 Mar. and 3 Apr. 1998 for $H$. radiatus and $H$. trionum, and 25 Mar. and 10 Apr. 1998 for $H$. coccineus. Plants were then grown at $22 \pm 2{ }^{\circ} \mathrm{C}\left(72 \pm 3{ }^{\circ} \mathrm{F}\right)$ under ambient light plus night interruption lighting [2 $\mu \mathrm{mol} \cdot \mathrm{m}^{-2} \cdot \mathrm{s}^{-1}$ (10 f.-c.) ], provided using incandescent lamps (Sylvania Directlite 100W; GTE Products Corp., Salem, Mass.), from 2200 to $0200 \mathrm{HR}$ daily. Treatments were initiated when the second true leaf unfolded (i.e., was parallel to the media surface).

There were nine growth retardant treatments established in a completely randomized statistical design with two replications per treatment and 10 plants per replication. Treatments consisted of a single spray application of about $6 \mathrm{~mL}$ ( $0.2 \mathrm{fl}$.) of 2500 or $5000 \mathrm{mg} \cdot \mathrm{L}^{-1}$ daminozide, 10 or 20 $\mathrm{mg} \cdot \mathrm{L}^{-1}$ paclobutrazol, 1000 or 2000 $\mathrm{mg} \cdot \mathrm{L}^{-1}$ chlormequat chloride, 5 or 10 $\mathrm{mg} \cdot \mathrm{L}^{-1}$ uniconazole or distilled water alone. Seedlings were sprayed until the entire seedling surface was covered.

Data were collected on leaf number and plant height (distance from the media surface to the apical meristem) on day 0,14 and 28 after spray application. Change in height was calculated. Date of first flower opening was recorded for $H$. trionum only, as this was the only species to flower during the experiment.

\section{Results and discussion}

Rate of deVelopment. Leaf unfolding rate of all three species did not vary between untreated plants, and plants in any growth retardant treatment. Hibiscus coccineus, $H$. radiatus, and $H$. trionum plants had 4, 6, and 6 leaves, respectively, $14 \mathrm{~d}$ after treatment, and 8,10 , and 9 leaves, respectively, $28 \mathrm{~d}$ after treatment. None of the plant growth retardants at any concentration studied delayed date of first flower opening of $H$. trionum, which flowered $26 \pm 1$ d after treatment.

Stem elongation. Species and growth retardant applied interacted to affect stem elongation of $H$. coccineus, $H$. radiatus, and $H$. trionum (Table 1). CCC applied at 1000 or 2000 $\mathrm{mg} \cdot \mathrm{L}^{-1}$ effectively inhibited stem elongation of all species at all time points (Table 1). This is consistent with previous reports on the efficacy of CCC on other hibiscus species (Shanks, 1972; Wang et al., 1998). When applied at 1000 and $2000 \mathrm{mg} \cdot \mathrm{L}^{-1}$, CCC resulted in excessive inhibition of $H$. coccineus stem elongation, reducing elongation by $80 \%$ and $88 \%$, respectively, $28 \mathrm{~d}$ after application. Therefore, CCC concentrations less than $1000 \mathrm{mg} \cdot \mathrm{L}^{-1}$ may be preferred for commercial production of $H$. coccineus, especially in northern climates.

Hibiscus coccineus plants sprayed with $2000 \mathrm{mg} \cdot \mathrm{L}^{-1}$ CCC exhibited foliar chlorosis about 3 to $5 \mathrm{~d}$ after application. After $28 \mathrm{~d}$, however, leaf color of previously chlorotic leaves was similar to leaves sprayed with water only. Tolbert (1960) reported an increase in chlorophyll content of wheat (Triticum aestioum L.) leaves after CCC application. The leaf chlorosis observed on $H$. coccineus after CCC application is consistent with results observed on other species, such as geranium (Pelargonium $\times$ hortorum Bailey) (Fonteno, 1992). This chlorosis is apparently due to chloroplast breakdown in expanding leaves (Barrett and Holcomb, 1993; Styer and Koranski, 1998). Cathey (1975) observed that this chlorosis is temporary in a wide range of bedding and vegetable plants. It appears that this temporary damage to chloroplasts is eventually compensated for by the chlormequat chloride-induced increase in leaf chlorophyll content.

In contrast to CCC, daminozide inhibited stem elongation of $H$. radiatus, but did not impact stem elongation of $H$. coccineus or $H$. trionum $28 \mathrm{~d}$ after application (Table 1 ). However, $H$. coccineus plants sprayed with daminozide exhibited reduced, though not statistically significant, stem elongation compared to control plants. Therefore, multiple applications or higher concentrations may be necessary to significantly reduce stem length using daminozide.

Paclobutrazol inhibited stem elongation of $H$. radiatus and $H$. trionum, but only marginally inhibited $H$. coccineus stem elongation $28 \mathrm{~d}$ after application (Table 1 ). Stem elongation of both $H$. coccineus and $H$. radiatus was strongly inhibited by paclobutrazol $14 \mathrm{~d}$ after application, but was similar to untreated plants from 14 to $28 \mathrm{~d}$ after application (Table 1). Therefore, multiple applications may be necessary for long-term height control.

Uniconazole inhibited stem elongation of $H$. radiatus, but did not impact $H$. trionum stem elongation and only marginally impacted stem elongation of $H$. coccineus $28 \mathrm{~d}$ after application (Table 1). However, uniconazole inhibited stem elongation of $\mathrm{H}$. trionum $\mathrm{l} 4 \mathrm{~d}$ after application (Table 1). Therefore, multiple applications, or higher concentrations, of uniconazole may be necessary for adequate height control of both $H$. coccineus and $H$. trionum.

At the highest concentrations applied, CCC $\left(2000 \mathrm{mg} \cdot \mathrm{L}^{-1}\right)$, paclobutrazol $\left(40 \mathrm{mg} \cdot \mathrm{L}^{-1}\right)$ and uniconazole $\left(10 \mathrm{mg} \cdot \mathrm{L}^{-1}\right)$ were equally effective (based on means separation test) in inhibiting stem elongation of $H$. coccineus $14 \mathrm{~d}$ after application (Table 1). However, by $28 \mathrm{~d}$ after application CCC applied at $2000 \mathrm{mg} \cdot \mathrm{L}^{-1}$ was the most effective in inhibiting $H$. coccineus stem elongation (Table 1 ). CCC applied at $2000 \mathrm{mg} \cdot \mathrm{L}^{-1}$ and paclobutrazol applied at $40 \mathrm{mg} \cdot \mathrm{L}^{-1}$ were equally effective in inhibiting $H$. radiatus stem elongation $28 \mathrm{~d}$ after application. Daminozide applied at $5000 \mathrm{mg} \cdot \mathrm{L}^{-1}$ and uniconazole applied at $10 \mathrm{mg} \cdot \mathrm{L}^{-1}$ also inhibited stem elongation of $H$. radiatus $28 \mathrm{~d}$ after application, but were less effective than CCC and paclobutrazol. Similar to $H$. radiatus, CCC applied at $2000 \mathrm{mg} \cdot \mathrm{L}^{-1}$ and paclobutrazol applied at $40 \mathrm{mg} \cdot \mathrm{L}^{-1}$ were equally effective in inhibiting $H$. trionum stem elongation $28 \mathrm{~d}$ after application.

This experiment employed a long photoperiod provided using low intensity incandescent lights in the middle of the night. It should be noted that stem elongation is promoted under lighting regimes with a low ratio of red (R) to far-red (FR) light (R:FR) (Smith, 1994). The R:FR of the incandescent lamps employed in this experiment was 0.73. Low R:FR (i.e., <l) can reduce growth regulator efficacy through promotion of stem elongation. Therefore, using natural photoperiod or using a lamp type with higher $\mathrm{R}: F R$ to provide the night-interruption would likely have resulted in less stem elongation. 
PGRs successfully inhibited stem elongation of the three Hibiscus spp. This information, combined with previously identified impacts of photoperiod and temperature on floral initiation of $H$. radiatus and $H$. trionum (Warner and Erwin, 2001) provide a basis for developing production schedules for these species. Further work is needed to understand floral inductive requirements of $H$. coccineus.

\section{Literature cited}

Barrett, J.E. and E.J. Holcomb. 1993. Growth regulating chemicals, p. 65-74. In: J.W. White (ed.). Geraniums IV. Ball Publ., Geneva, Ill.

Bickford, E.D. and S. Dunn. 1972. Lighting for plant growth. Kent State Univ. Press. Ashland, Ohio.

Bose, T.K., B.K. Hore, and D. Mukherjee. 1968. Dwarfing of some malvaceous ornamental plants as a nursery practice. HortScience 3:179-180.

Cathey, H.M. 1975. Comparative plant growth-retarding activities of ancymidol with ACPC, phosfan, chlormequat, and SADH on ornamental plant species. HortScience 10:204-216.

Dole, J.M and H.F. Wilkins. 1999. Hibiscus, p. 368-372. In: Floriculture: Principles and species. Prentice Hall, Upper Saddle River, N.J.

Fonteno, W.C. 1992. Geraniums, p. 452477. In: R.A. Larson (ed.). Introduction to floriculture. $2^{\text {nd }}$ ed. Academic Press Inc., San Diego, Calif.

Gianfaga, T.J. 1995. Natural and synthetic growth regulators and their use in horticultural and agronomic crops, p. 614-635. In: P.J. Davies (ed.). Plant hormones: Physiology, biochemistry, and molecular biology. $2^{\text {nd }}$ ed. Martinus Nijhoff Publ., Dodrecht, Netherlands.

Grossman, K. 1988. Plant growth suspensions for screening and studying the mode of action of plant growth retardants, p. 89136. In: K. Maraorosch and G. Sato (eds.). Advances in cell culture. Academic Press Inc., San Diego, Calif.

Grossman, K. 1992. Plant growth retardants: their mode of action and benefit for physiological research, p. 788-797. In: C.M. Karssen, L.C. Van Loon, and D. Vreugdenhl(eds.). Progress in plant growth regulation. Kluwer Academic Publ., Dodrecht, Netherlands.
Menhennet, R. 1980. Evidence that daminozide, but not two other growth retardants, modifies the fate of applied gibberellin $\mathrm{A}_{9}$ in Chyrsanthemum morifolium Ramat. J. Expt. Bot. 31:16311642 .

Rademacher, W. 1991. Inhibitors of gibberellin biosynthesis: applications in agriculture and horticulture, p. 296-310. In: N. Takahashi, B.O. Phinney, and J. MacMillan (eds.). Gibberellins. SpringerVerlag, New York.

Sachs, R.M., A. Lang, C.F. Bretz, and J. Roach. 1960. Shoot histogenesis: subapical meristematic activity in a caulescent plant and the action of gibberellic acid and AMO-1618. Amer. J. Bot. 47:260-266.

Shanks, J.B. 1972. Chemical control of growth and flowering in hibiscus. HortScience 7:574.

Smith, H. 1994. Sensing the light environment: The functions of the phytochrome family, p. 377-416. In: R.E. Kendrick and G.H.M. Kronenberg (eds.). Photomorphogensis in plants. $2^{\text {nd }}$ ed. Kluwer Academic Publ., Dodrecht, Netherlands.

Styer, R.C. and D.S. Koranski. 1998. Plug and transplant production: A grower's guide. Ball Publ., Batavia, Ill.

Takeno, K., R.L. Legge, and R.P. Pharis. 1981. Effect of the growth retardant B-9 (SADH) on endogenous GA level, and transport and conversion of exogenously applied $\left[\mathrm{H}^{3}\right] \mathrm{GA}_{20}$ in Alaska pea. Plant Physiol. 67(Suppl):581(abstr.).

Tolbert, N.E. 1960. (2-chloroethyl) trimethylammonium chloride and related compounds as plant growth substances II. Effect on growth of wheat. Plant Physiol. 35:380-385.

Wang, S., R.D. Heins, W. Carlson, and A. Cameron. 1998. Forcing perennials: $\mathrm{Hi}$ biscus moschentos 'Disco Belle Mixed'. Greenhouse Grower 16(2):29-32.

Wang, Y. and L.L Gregg. 1991. Modification of hibiscus growth by treating unrooted cuttings and potted plants with uniconazole or paclobutrazol. J. Plant Growth Regulat. 10:47-51.

Warner, R.M. and J.E. Erwin. 2001. Variation in flower induction requirements of Hibiscus sp. J. Amer. Soc. Hort. Sci. 126:262-268.

Wilkins, H.F. and D. Kotecki. 1982. Hibiscus rosa-sinensis L. Minn. State Florists Bul. 31:3-7.

\section{Yield and Quality of Machine Harvested Red Chile Peppers}

\author{
Marisa M. Wall, ${ }^{1}$ \\ Stephanie Walker, ${ }^{2}$ \\ Arthur D. Wall, ${ }^{3}$ Ed Hughs, ${ }^{4}$ \\ and Richard Phillips ${ }^{5}$
}

Additional index words. Capsicum annuum, mechanical harvest, ethephon, paprika, vegetable crops.

SUmmarY. In the southwestern U.S. growing region, which includes southern New Mexico, west Texas, and southeastern Arizona, mechanical harvest of chile peppers (Capsicum annuum) is increasing because of the high cost of hand labor. Mechanical harvesters have been developed, but there is limited information on the performance of chile cultivars when machine harvested. Four red chile pepper cultivars (New Mexico 6-4, Sonora, B-18, and B-58) were grown in a farmer's field near Las Cruces, N.M., and harvested in October 2000 using a double-helix-type harvester. Ethephon was applied 3 weeks before harvest at $1.5 \mathrm{pt} /$ acre $\left(1.75 \mathrm{~L} \cdot \mathrm{ha}^{-1}\right)$ to promote uniform ripening. Ethephon caused fruit of 'B-18' and 'B-58' to drop before harvest, thereby affecting yield results. Treatment with ethylene-releasing compounds is not recommended for these cultivars. 'Sonora' and 'New Mexico 6-4'

Department of Agronomy and Horticulture, MSC 3Q, Box 30003, New Mexico State University, Las Cruces, NM 88003-0003.

This research was supported by the New Mexico Agricultural Experiment Station, and the New Mexico Chile Pepper Task Force. We thank Steve Lyles for producing the crop; Roy Pennock, Linda Liess and Margery Parossien for technical assistance; Jim McClendon, McClendon Pepper Co., Tulia, Texas, for custom harvest; and Biad Chili Co., Leasburg, N.M., for dehydrating the crop.

${ }^{1}$ Former professor and corresponding author (mwall@pbarc.ars.usda.gov). Current address: U.S. Pacific Basin Agricultural Research Center, USDAARS, P.O. Box 4459, Hilo, HI 96720-0459.

${ }^{2}$ Research specialist.

${ }^{3}$ Former assistant professor. Current address: P.O. Box 301, Honomu, HI 96728-0301.

${ }^{4}$ Supervisory agricultural engineer. USDA-ARS, Southwestern Cottoning Ginning Research Laboratory, P.O. Box 578, Mesilla Park, NM 88047.

${ }^{5}$ Project manager, New Mexico Chile Task Force. Department of Extension Plant Sciences, MSC 3AE, Box 30003, New Mexico State University, Las Cruces, NM 88003-0003. 